\title{
The Effect of Storage Diversity on the Breaking Strength and Elongation of Polyamide Monofilament in Gill Net Fishing Gear
}

\author{
Herry Boesono $^{1 *}$, Fadhila Surya Layli ${ }^{1}$, Agus Suherman ${ }^{1}$, Bogi Budi Jayanto ${ }^{1}$ and \\ Arief Yudhi Susanto ${ }^{2}$ \\ ${ }^{1}$ Department of Fisheries Resources Utilization, Faculty of Fisheries and Marine Science, Diponegoro \\ University, Semarang, Central Java 50275, Indonesia \\ ${ }^{2} P$ T. Arteria Daya Mulia (ARIDA), Cirebon, West Java 45113, Indonesia
}

\begin{abstract}
The study aimed to determine the breaking strength and elongation of polyamide monofilament $0.44 \mathrm{~mm}$ in dry condition after treating with open and close storage. This study was an experimental study that refers to SNI ISO 1805: 2010 method. Data collection was done in the dry condition with two yarn samples from different treatments and one sample as a control. Each treatment was done 10 times of repetition. The test material was collected in one mesh. Then the locking distance was adjusted with the mesh size. The breaking strength and elongation score were tested using an autograph. The study found the breaking strength on polyamide nets stored closely was higher than open storage samples. On the other, the elongation value on monofilament polyamide nets stored closely was lower than open storage samples. There was an effect on different storage methods against polyamide breaking strength (sig 0.00), which was lower than $\alpha(0.05)$. Different storage methods also affected the elongation score of polyamides ( $\operatorname{sig} 0.00)<\alpha(0.05)$. In conclusion, there was an effect on different storage methods, open or close storage, against breaking and elongation strength of polyamide monofilament $0.4 \mathrm{~mm}$.
\end{abstract}

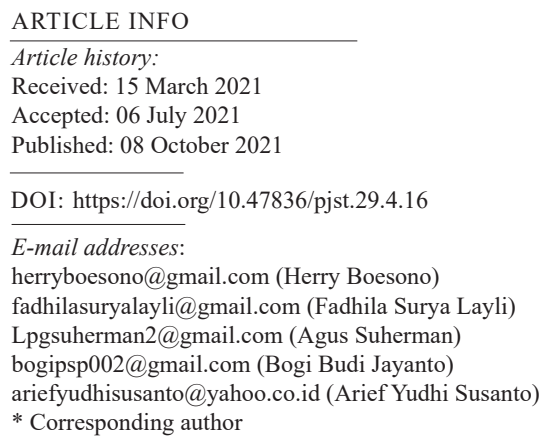

Keywords: Breaking strength, elongation, fish, gill net, polyamide, synthetic fibre

\section{INTRODUCTION}

There are two types of fishing gear based on basic materials, such as natural and synthetic fibre. Natural fibre is made up of natural material without any chemical process or transformation. Natural fibre can be obtained from plants or animals bodies-however, 
synthetic fibre is obtained from the polymerisation process of monomers. Natural fibres are not being used as the primary material of fishing gear due to low material durability. Therefore, synthetic fibre is more commonly used to make fishing gear compared to natural fibre. Synthetic is a scientific and technical term for a chemical process, such as chemical elements that have been combined and strengthened by the factory with new properties (Puspito, 2009). Synthetics fibres are essential substances like phenol, benzene, acetylene, prussic acid, and chlorine. Basic materials that make up artificial fibre are known as synthetic fibre (Ardidja, 2010).

The durability of synthetic yarn is seen from its breaking strength and elongation score. Yarn breaking strength and elongation score are the value of yarn synthetic durability against the tensile force (Klust, 1987). Breaking strength is tested by a machine with different capabilities against the maximum load that can be borne (Ramos, 1999). Elongation is the elasticity value of synthetic yarn. Therefore, the breaking strength and elongation score is an important part that needs to be considered. If the value of breaking strength is high and has low elongation, it can increase material effectivity (Sari et al., 2017). A synthetic fibre made from chemicals to be the primary material of fishing gear commonly used by fishermen is polyamide, polyethene, and polyvinyl chloride. Those materials are from plastics type low-density polyethene (LDPE) (Mainnah et al., 2016).

One of the fishing gear made from polyamide as the primary material is a gill net. A gillnet is a rectangular fishing gear made from polyamide monofilament or multifilament with the same mesh size. A gillnet is a type of gilled gear because fish mostly catch on the gill cover as its way of passing through the net (Brant, 1984). A gillnet is installed vertically against the water surface and block the direction of fish movement (Making et al., 2014). Fishing nets are a passive catching tool (Nurdin, 2009) with a completed buoy, ballast, head, and under the rope or without under rope to block fish direction movement to be cached to the net (Fachrudin, 2012). Polyamide or nylon material is chosen as the basic material of the gill net due to its characteristic that fits like a basic material of the gill net (Rahmadhani et al., 2017).

Gillnet can be used or operated by big boat fishermen or on an industrial scale and small boat/traditional fishers. Drop net or setting step is done in a few hours in accordance with the fishermen that operate it (Sulaeman, 2008). The installation step of the net is started by the drop of marker buoy tied up with slingshot. The piece drops one by one until the net is entirely spread and soaked for a few hours. The next step is a net withdrawal that starts from the marker buoy, pulled using a roller. When the net is withdrawn, the catch is taken (Putra, 2007). Traditional fishers with their small boat in Tambaklorok, Semarang City, have different habits in storing the fishing gear, either open or closed storage. Open storage is a way of keeping the habit of fishers that store the gill net on the boat without being covered, where close storage is when the gill net is stored on the boat that is covered by cloth and tarpaulin. 
The improvement in the use of synthetic yarn still has a weakness. Synthetic fibres can experience a quality decline due to environmental factors such as ultraviolet (UV) light exposure. UV affected the value of fibre synthetic breaking strength (Al-Oufi et al., 2003). Furthermore, direct and continuous sunlight exposure can cause weathering. Weathering can modify and ruin the structure of polymer molecules, which finally caused the loss of the strength and extensibility, durability, and general performance of polyamide yarn (Thomas $\&$ Hridayanathan, 2006). Based on the weakness of synthetic yarn, it is necessary to test the polyamide yarn on the gill net, which is stored in a different place to find a suitable gill net storage method and make the gill net last longer. Synthetic materials have been rapidly developed in the fishing industry and able to make the industry smoother. The improvement of the use of synthetic fibre is currently being considered because of its characteristic that it is difficult to be rot, which affects the environment (Kim et al., 2016). Therefore, the present study aimed to determine the breaking strength and elongation of polyamide monofilament $0.44 \mathrm{~mm}$ in dry condition after treating with open and close storage.

\section{MATERIALS AND METHODS}

\section{Materials}

Materials used in the study were net samples obtained from fishers that used polyamide gill net $0.4 \mathrm{~mm}$ and 6 months of service life. Samples were collected from different storage treatments on a different boat, kept closed (using a tarpaulin) and kept openly (Figure 1). Sampling was conducted in Tambaklorok Village, North Semarang District, Semarang City, Central Java. Tambaklorok gill net fishers have been an arrest operation for 6 to 7 hours per day and off on Friday. Gillnet used a basic gill net that usually changed after 1 to 2 years and repaired every day off or when severe damage was found in the gill net. In addition, mesh samples were taken from the net body, which was still good or not yet damaged.

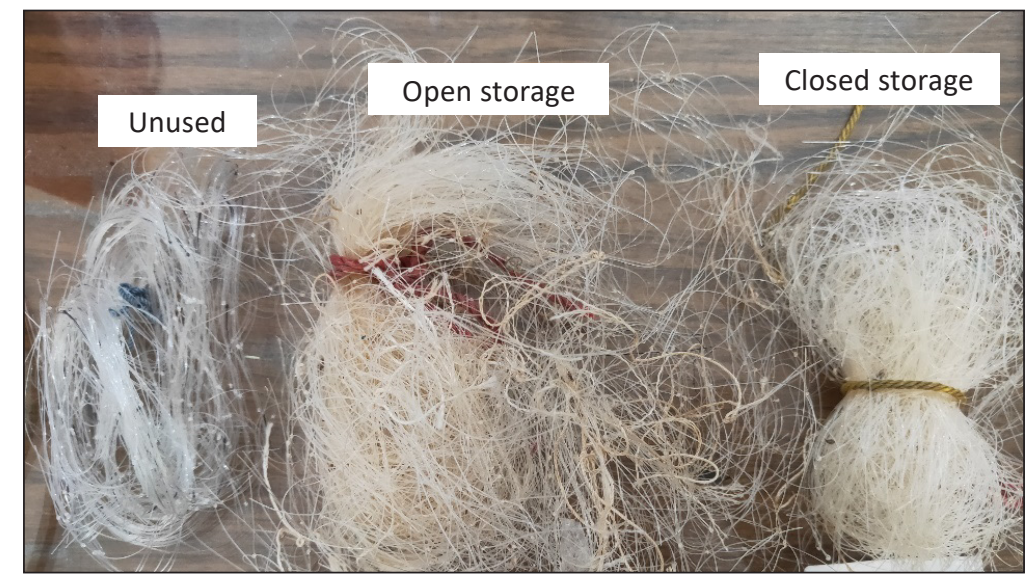

Figure 1. Net sample 


\section{Experimental Design}

The experimental design was a method used in this study and to know the effect of different storage methods on the durability of the gill net. The study was conducted by finding samples in accordance with the original conditions of the object of research. The field survey was done to find gill net that is being stored differently. Samples were chosen based on the difference between open and closed storage, with several variables that must be equated. In addition, variables must be correlated, such as gillnet, service life, usage time, mesh size, and net diameter. Sample test results were compared with test results of unused nets as control (deemed according to the standard) to see the differences in test results.

The test of the samples was done in the quality control room PT ARIDA. The materials used were net samples obtained from fishers using polyamide material of gill net $0.4 \mathrm{~mm}$, have the same operational life from different storage treatments on the boat, namely closed storage (using a tarpaulin) and open storage. The test was done in the dry condition against net samples from three groups, including the control group (untreated net), net samples being treated with open storage (open storage group , and net samples with closed storage (closed storage group). There were 10 repetitions of each group according to SNI ISO 1805:2010, at least 10 times valid repetitions against each sample test that must be done (Indonesia National Standard, 2010). The following process was materials tested obtained from one mesh of each test. Breaking strength and elongation were tested using a breaking strength machine and Trapezium II application.

\section{Data Analysis}

The hypothesis of the study was:

1. Breaking strength

$\mathrm{H}_{\mathrm{o}}$ : no effect found in different treatments against yarn breaking strength.

H1: different treatments affected yarn breaking strength.

2. Elongation

$\mathrm{H}_{\mathrm{o}}$ : no effect found in different treatments against yarn elongation.

H1: different treatments affected yarn elongation.

The data analysis was done to know the effect of different treatments against breaking strength and elongation of polyamide yarn by Kruskal-Wallis of the non-parametric test (because data results do not spread normally). The process of data analysis was done using SPSS Software with the following decision-making rules:

- Know the effect of treatments on breaking strength and elongation (Kruskal-Wallis test) with a probability of 0.05 .

Asymp. Value sig $>0.05$, then Ho was accepted.

Asymp. Value sig $<0.05$, then Ho was rejected. 
- Know the comparison between factors (Mann-Whitney test) with a probability of 0.05 .

Asymp. Value sig $>0.05$, then Ho was accepted.

Asymp. Value sig $<0.05$, then Ho was rejected.

\section{RESULTS AND DISCUSSION}

\section{General View of the Sample Collection Location}

Sample collection was done in Tambaklorok Village, North Semarang District, Semarang City, Central Java. Mostly, the profession of the population were fishermen. The fishing gear used by Tambaklorok fishermen were varied; one of those was gill net fishing gear. Tambaklorok fishers stored their gill net by covering it with tarpaulin and tied it not to be stolen and damaged. Some fishermen who use the gill net almost every day usually store it openly to reduce their time to open or close the cover after being used. The fishermen did not consider the effect of the storage method on net durability. The fishermen only consider its age and level of damage or replace or repair the fishing gear.

\section{The Autograph Machine Test Results}

Autograph machine output showed a time graph; therefore, it can be seen whether the net breaks at a standard time or not and at what range of tensile strength values caused the net to break.

Figure 2 showed the new nets in 10 times test would break at strength 5-6 Kgf in 20-23 seconds. The unused nets showed

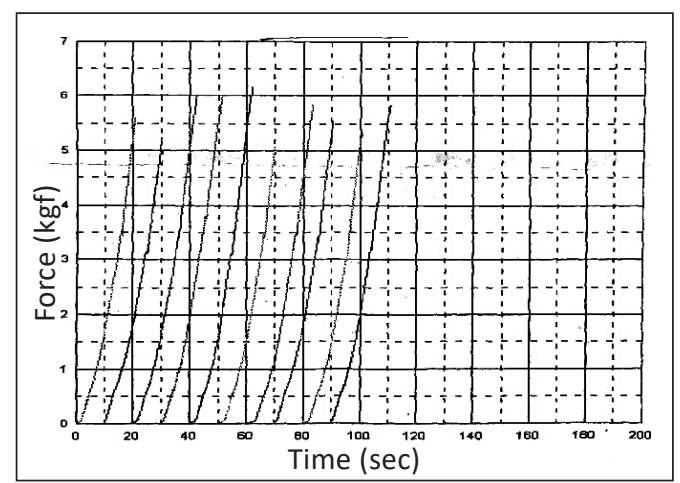

(a)

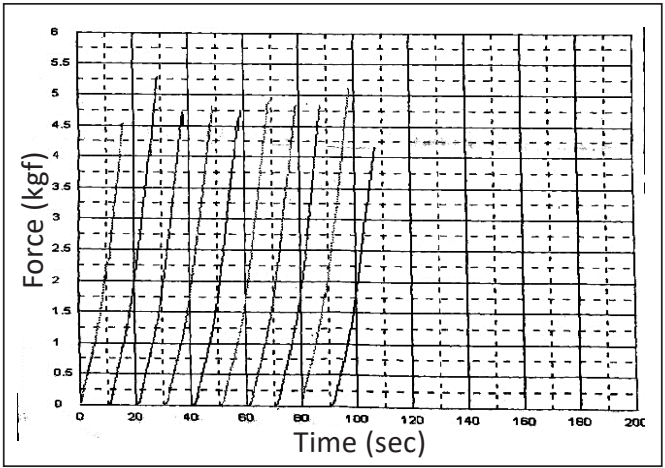

(b)

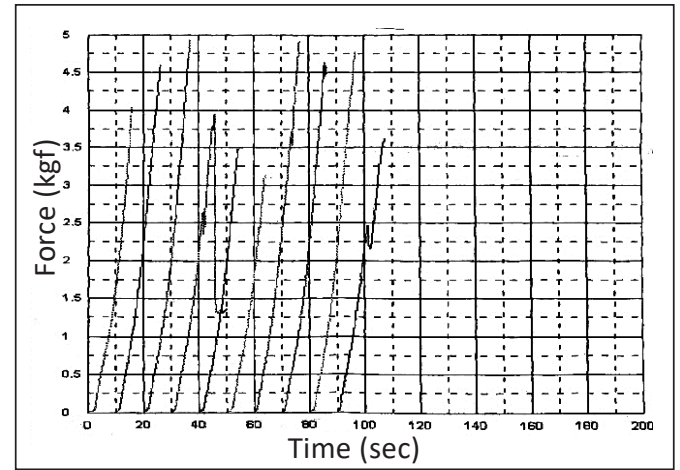

(c)

Figure 2. Graph of autograph machine test results: (a) Graph of unused nets test results; (b) Closed storage net test result graph; (c) Graph of open storage net test results 


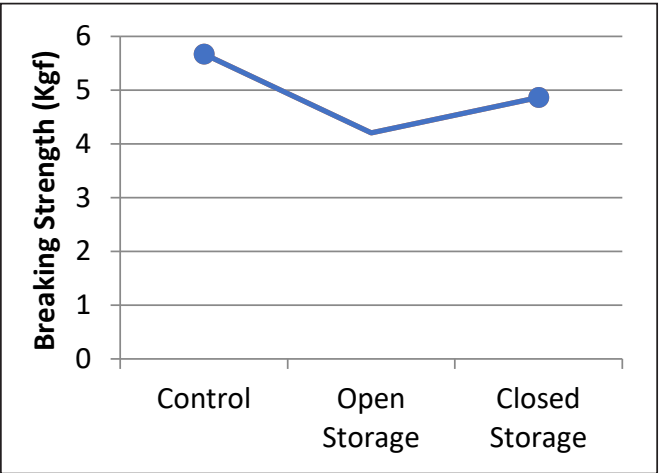

Figure 3. Average of breaking strength

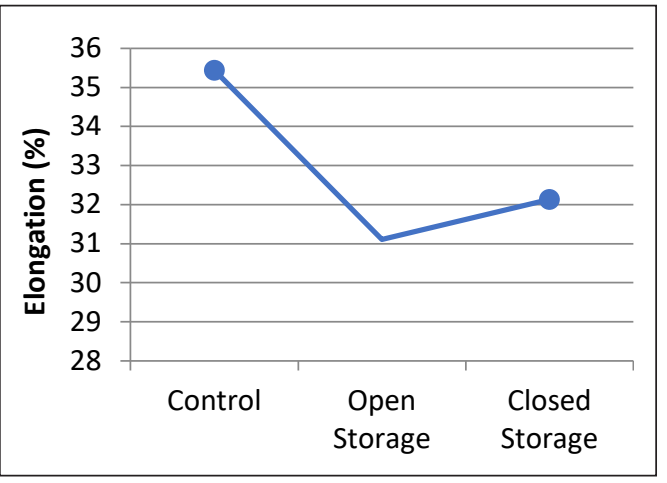

Figure 4. Elongation average graph

good resistance. Figure 3 showed that the gill net stored closely on 10 times test would break at strength 4-5 Kgf in less than 20 seconds. The breaking strength of this group was lower than the control group. Figure 3 showed that net in open storage after 10 times test would break at strength 3-4 Kgf in less than 20 seconds. Based on Figure 4, the graph declined after breaking due to the durability reduction of the net stored openly. Thus, the open storage method of nets showed lower durability compare to nets that stored closely.

Breaking Strength of Nets in Different Storage. The breaking strength test was done by giving a load to the net until the net breaks so that the maximum load received by the net can be seen. The breaking strength test was done in 3 groups (Figure 3). The unused nets as control were compared with treated nets, whether open storage treatment or closed storage. The test was done according to the National Standard of Indonesia (NSI), and the results were shown in Table 1.

Table 1

Breaking strength test results

\begin{tabular}{cccc}
\hline No & \multicolumn{3}{c}{ Breaking strength value (Kgf) } \\
\cline { 2 - 4 } & Unused nets & Open storage & Closed storage \\
\hline 1 & 5.09 & 3.15 & 4.54 \\
3 & 5.25 & 3.49 & 4.72 \\
4 & 5.34 & 3.63 & 4.77 \\
5 & 5.55 & 3.96 & 4.81 \\
6 & 5.6 & 4.04 & 4.82 \\
7 & 5.83 & 4.6 & 4.85 \\
8 & 5.86 & 4.64 & 4.86 \\
9 & 6 & 4.78 & 4.91 \\
10 & 6.01 & 4.91 & 5.13 \\
Average & 6.16 & 4.93 & 5.31 \\
\hline
\end{tabular}

Kgf = Kilogram Force 
Breaking strength value declined after the nets being used (Figure 3). The decline of its breaking strength is caused by many factors, such as net material quality or usage factor. Quality factor influenced by material quality used to make the net because each net has a different structure. Usage factor was a factor that affects net breaking strength after being used. Immersion nets also influenced the decline of nets breaking strength.

Elongation of Nets in Different Storage. Elongation nets test was done in 3 groups as the groups in breaking strength test. Unused nets was a control that being compared with open and closed nets storage. The test was done according to NSI with wet test method at $20^{\circ}-21^{\circ} \mathrm{C}$ room temperature and 100 force load. Based on the elongation test, the results are shown in Table 2.

Table 2

Net elongation test results

\begin{tabular}{cccc}
\hline No & \multicolumn{3}{c}{ Elongation $(\%)$} \\
\cline { 2 - 4 } & Unused nets & Open storage & Closed storage \\
\hline 1 & 33.27 & 27.25 & 28.67 \\
3 & 33.9 & 27.84 & 30.82 \\
4 & 34.33 & 30.62 & 31.26 \\
5 & 34.51 & 30.84 & 31.34 \\
6 & 34.64 & 31 & 32.51 \\
7 & 34.95 & 31.58 & 32.92 \\
8 & 35.64 & 32.28 & 33.2 \\
9 & 36.71 & 32.88 & 33.5 \\
10 & 37.46 & 33.07 & 33.5 \\
Average & 38.96 & 33.74 & 33.64 \\
\hline
\end{tabular}

The results of the nets elongation value test showed a decline after being used (Figure 4). The elongation value was lower not because of a better elongation, but the nets were already not elastic. The breaking strength of open storage nets was lower so that with the same strength, the nets would break before reaching the breaking strength standard, so the elongation was small. It also can be observed physically; the mesh shifted because the elongation nets and breaks easily because the breaking strength value of nets open storage was low.

The elongation value of the tested nets was decreased after use. The smaller elongation value is not because the elongation is getting better but, the net is no longer experiencing elongation. The breaking strength value in an openly stored net is getting smaller so that with the same strength, the net will break before reaching the standard breaking strength and then the elongation value is small. The mesh has physically shifted because the net is 
stretched and breaks because the breaking strength value of the net kept open is also small. According to Ardidja (2010), threads with high elasticity can return to their original shape and size or leave a small elongation. This condition also guarantees whether the mesh size remains constant and can maintain its strength.

Treatments Effect on Breaking Strength. The results of the non-parametric through Kruskal-Wallis test $(\alpha=0.05)$ showed the breaking strength affected differently by the treatments. The polyamide nets showed P-value $<0.05$ or 0.000 , which means $\mathrm{H} 0$ was rejected and $\mathrm{H} 1$ accepted. It shows the different storage methods that affected breaking strength.

The Mann-Whitney test was done to know the treatment that gave the actual effect on breaking strength nets. Based on this test, control, open storage, and closed storage treatments showed the results in Table 3. The results showed that the breaking strength of each treatment showed significant differences. In the group of open storage, nets showed a lower breaking strength value than closed storage nets breaking strength, so closed storage was preferred to maintain the quality of the net.

Table 3

Mann Whitney test results of treatments effect on breaking strength

\begin{tabular}{cccc}
\hline Groups & Z-value count & P-value & Indication \\
\hline Control vs Open & -3.780 & 0.000 & Significantly different \\
Control vs Closed & -3.553 & 0.000 & Significantly different \\
Open vs Closed & -2.231 & 0.026 & Significantly different \\
\hline
\end{tabular}

Treatments Effect on Elongation. The analysis of non-parametric using Kruskal-Wallis with 5\% test level $(\alpha=0.05)$ showed that the nets elongation of all group were affected. Polyamide yarn showed P-value $<0.05$ (0.000), which means H0 was rejected and H1 accepted (different storage methods affected elongation score). Mann-Whitney test results were shown in Table 4.

Table 4

Mann Whitney test results of treatments effect on elongation

\begin{tabular}{cccc}
\hline Groups & Z-value count & P-value & Indication \\
\hline Control vs Open & -3.554 & 0.000 & Significantly different \\
Control vs Closed & -3.704 & 0.000 & Significantly different \\
Open vs Closed & -1.286 & 0.199 & Not significantly different \\
\hline
\end{tabular}

The population majority was fishermen and catching tools they operated, such as arad fishing gear, gill net, and trammel net (Putri et al., 2018). The basic gill net was a catching tool to catch demersal fish. Fish that could be cached by Tambaklorok fishermen using a 
basic gill net were Nibea albiflora and Rastrellinger sp. The catch target of basic gill net was demersal fish such as Nibea albiflora and Leiognathidae. The catch of basic gill net in northern waters such as pelagic fish, including Rastrellinger sp. (Gunawan et al., 2016).

The way of how gill net catch was fish spun into the nets, making the net elastics (has lower breaking strength because the maximum load that can be borne was also getting smaller). Breaking strength was the maximum strength that needs to break the material in a test that uses tension. The unit of breaking strength is a kilogram of force (Kgf) (Fadhari et al., 2015). Yarn with high elasticity can be back to the first shape and size or leaving little elongation. That condition also guaranteed whether net mesh size was constant and maintained its strength (Aridja, 2010).

Open storage nets usually done on the boat reduced the breaking strength faster than closed storage. It was caused by the polyamide material that was susceptible to UV light. A good gill net has a high breaking strength value, meaning that the net can withstand a greater load. The best fishing gear yarn was yarn with low durability but had a high breaking strength value (Fadhari et al., 2015).

The results of statistical elongation data analysis showed the different elongation scores between new and used nets. The elongation score was reduced due to the application of the net. This result showed that open storage has a lower elongation score but did not break in the standard time and meet the standard charts. The elongation score of open and closed storage did not differ significantly because the breaking strength of both groups reduced that affected elongation and experienced construction modification such as cover shift due to use. Too high elongation can modify nets construction such as cover shift and mesh size. Stretched nets make the mesh size bigger so that the fish can easily catch (Fadhari et al., 2015).

\section{CONCLUSION}

The breaking strength of Polyamide monofilament $0.4 \mathrm{~mm}$ nets that have been stored openly and closely were $4.21 \mathrm{Kgf}$ and $4.81 \mathrm{Kgf}$, respectively. The elongation score of Polyamide monofilament $0.4 \mathrm{~mm}$ nets that have been stored openly and closely were $32.14 \%$ and $31.11 \%$, respectively. There was a different storage effect on breaking strength of Polyamide monofilament $0.4 \mathrm{~mm}$ nets. The nets of closed storage showed a higher breaking strength compare to open storage. In addition, there was a different storage effect on the elongation of Polyamide monofilament $0.4 \mathrm{~mm}$ nets. The nets of closed storage showed a higher elongation compare to open storage. The suggestion of this study was to store the gill net closely and avoid direct sunlight exposure. 


\section{ACKNOWLEDGMENTS}

The authors wish to thank Fakultas Perikanan dan Ilmu Kelautan Universitas Diponegoro, Lembaga Penelitian dan Pengabdian Masyarakat (LPPM) Universitas Diponegoro dan PT. Arteria Daya Mulia (ARIDA) Cirebon City, West Java, Indonesia.

\section{REFERENCES}

Al-Ouf, H., McLean, E., Kumar, A. S., Claereboudt, M., \& Al-Habsi, M. (2003). The effects of solar radiation upon breaking strength and elongation of fishing nets. Fisheries Research, 6(1), 115-119. https://doi. org/10.1016/S0165-7836(03)00103-6

Ardidja, S. (2010). Bahan alat penangkap ikan [Fishing equipment material]. STP Press.

Brant, A. V. (1984). Fish catching methods of the world. Fishing News Books Ltd.

Fachrudin, H. (2012). Petunjuk teknis perikanan tangkap: Identifikasi jaring insang (Gill net) [Capture fisheries technical instructions: Gill net identification]. Balai Besar Penangkapan Ikan.

Fadhari, A., Isnaniah, I., \& Nofrizal, N. (2015). Study on strength broke and elongation yarn PA (Polyamide) with addition of skin stem extract salam (Syzygium polyanthum) with different concentration. Jurnal Online Mahasiswa Fakultas Perikanan dan Ilmu Kelautan Universitas Riau, 2(1), 1-12.

Gunawan, A. A., Ismail, I., \& Jayanto, B. B. (2016). Analisis finansial usaha perikanan jaring klitik (Gill net dasar) dan jaring nilon (Gill net permukaan) di pangkalan pendaratan ikan (PPI) Tanjungsari Kabupaten Pemalang, Jawa Tengah [Financial analysis of fishery business clitic nets (Basic gill nets) and nylon nets (Surface gill nets) at the Tanjungsari fish landing base (PPI) Pemalang Regency, Central Java]. Journal of Fisheries Resources Utilization Management and Technology (JFRUMT), 5(2), 48-54.

Indonesia National Standard. (2010). SNI ISO 1805. Alat penangkap ikan berbahan jaring-Penentuan gaya putus mata jaring [Fishing equipment made from nets - Determination of net eye breaking force]. Indonesia National Standard.

Kim, S., Kim, P., Lim, J., An, H., \& Suuronen, P. (2016). Use of biodegradable driftnets to prevent ghost fishing: Physical properties and fishing performance for yellow croaker. Animal Conservation, 19(4), 309-319. https://doi.org/10.1111/acv.12256

Klust, G. (1987). Bahan jaring untuk penangkakpan ikan [Material for fishing nets]. In Tim BPPI Semarang (Trans.), Bagian proyek pengembangan teknik penangkapan ikan (Edisi 2) [Fishing technique development project section (2nd Ed.)]. Balai Penangkapan Ikan.

Mainnah, M., Diniah, D., \& Iskandar, B. H. (2016). Perpaduan serat daun nanas (Ananas Comosus) dan kitosan sebagai material alat penangkapan ikan ramah lingkungan [Combination of pineapple leaf fiber (Ananas Comosus) and chitosan as environmentally friendly fishing equipment material]. Marine Fisheries, 7(2), 149-159.

Making, A. D. L., Asriyanto, A., \& Yulianto, T. (2014). Pengaruh perbedaan mata jaring (Mesh size) gillnet terhadap cara tertangkap ikan kembung perempuan (Scomber neglectus) di perairan Morodemak, Kabupaten Demak [The effect of difference in mesh size of gillnet on how to catch female mackerel fish 
(Scomber Neglectus) in Morodemak waters, Demak Regency]. Journal of Fisheries Resources Utilization Management and Technology (JFRUMT), 3(4), 120-129.

Nurdin, E. (2009). Perikanan tuna skala rakyat (Small scale) di prigi, Trenggalek-Jawa Timur [Small scale tuna fishery in prigi, Trenggalek-East Java]. BAWAL: Widya Riset Perikanan Tangkap, 2(4), 177-183. http://dx.doi.org/10.15578/bawal.2.4.2009.177-183

Puspito, G. (2009). Perubahan sifat-sifat fisik mata jaringan insang hanyut setelah digunakan 5, 10, 15, dan 20 tahun [Changes in the physical properties of the eye gill tissue after being used for 5, 10, 15, and 20 years]. Jurnal Penelitian Sains, 12(3), 1-6. https://doi.org/10.26554/jps.v12i3.172

Putra, I. (2007). Deskripsi dan analisis hasil tangkapan jaring millenium di Indramayu [Description and analysis of millennium net catches in Indramayu]. Institut Pertanian Bogor.

Putri, V. L., Kurohman, F., \& Fitri, A. D. P. (2018). Efisiensi teknis dan selektivitas alat tangkap jaring insang (Gillnet) terhadap komposisi hasil tangkapan di perairan Semarang [Technical efficiency and selectivity of gillnet fishing equipment on composition of catches in Semarang waters]. Saintek Perikanan: Indonesian Journal of Fisheries Science and Technology, 13(2), 126-132. https://doi.org/10.14710/ijfst.13.2.126-132

Rahmadhani, T., Syofian, I., \& Nasution, P. (2017). Studi perubahan panjang benang jaring polyamide (PA) yang direndam didalam air tawar dan air laut [Study of changes in length of polyamide net yarn (PA) soaked in freshwater and sea water]. Jurnal Online Mahasiswa Fakultas Perikanan dan Ilmu Kelautan Universitas Riau, 4, 1-12.

Ramos, J. M. L. (1999). Chemical and physical properties of synthetic fibres most commonly used in fishing gear, with reference to their use in cape Verde fisheries. Fisheries Training Program, 1, 1-26.

Sari, V. A. P., Boesono, H., \& Setiyanto, I. (2017). Analisis pengaruh media perendaman benang PA multifilamen D21 terhadap kekuatan putus (Breaking strength) dan kemuluran (Elongation) dengan metode SNI ISO 1805: 2010 [Analysis of the effect of soaking media for PA multifilament D21 yarn on breaking strength and elongation with SNI ISO 1805: 2010 method]. Journal of Fisheries Resources Utilization Management and Technology, 6(4), 168-174.

Sulaeman, M. (2008). Jaring insang [Gill net] (3rd Ed.). Institut Pertanian Bogor.

Thomas, N. S., \& Hridayanathan, C. (2006). The effect of natural sunlight on the strength of polyamide 6 multifilament and monofilament fishing net materials. Fisheries Research, 1(2-3), 326-320. https://doi. org/10.1016/j.fishres.2006.06.012 
